\title{
ESTIMATING THE COST OF PRODUCT RECYCLING WITH THE USE OF ECODESIGN SUPPORT SYSTEM
}

\author{
Anna Karwasz ${ }^{1}$, Ewa Dostatni ${ }^{1}$, Jacek Diakun ${ }^{1}$, Damian Grajewski ${ }^{1}$, \\ Radosław Wichniarek ${ }^{1}$, Marek Stachura ${ }^{2}$ \\ ${ }^{1}$ Poznan University of Technology, Faculty of Mechanical Engineering and Management, Poland \\ ${ }^{2}$ KERP Center of Excellence Electronics $\& 3$ Environment, Design for Environment, Austria
}

Corresponding author:

Anna Karwasz

Poznań University of Technology

Faculty of Mechanical Engineering and Management

Chair of Management and Production Engineering

Piotrowo 3, 60-965 Poznań, Poland

phone: $(+48) 61665-2 \%-18$

e-mail: anna.karwasz@put.poznan.pl

Received: 22 August 2015

Accepted: 19 February 2016
ABstract

The paper focuses on issues associated with the ecodesign of household appliances. The authors describe the estimation of recycling cost of end-of-life products using their original system supporting ecodesign. The cost estimate was conducted during product design stage using the information stored in CAD 3D system. A sample estimate was made for a washing machine, fridge, kettle, and a hairdryer.

KEYWORDS

ecodesign, CAD, recycling, product modeling, household appliance.

\section{Introduction}

The risks related to products, which have reached the end of their life cycle is a global problem and applies to our entire environment. Everyone has their share and influence on the reduction of negative impact of waste.

The number of household products reaching the end of their life grows every year. Obviously, the vast volume of waste generated in a short period of time constitutes a real problem. Due to the composition of the products (content of metals, plastics, hazardous substances, etc.) they are a serious burden for the environment. Waste is not only a threat to the environment; it can be a valuable source of raw materials, the recovery of which brings not only environmental but also economic benefits. It is therefore necessary to introduce actions involving proper utilization of such waste and its recycling [1].

The volume of used equipment and the risks to the environment require that specific procedures of waste management be implemented. End-of-life equipment must be properly utilized: it may be reused, recycled or otherwise recovered.

Processing of waste from used household appliances, including washing machines, is good not only due to environment protection, but also due to financial reasons: even products withdrawn from use have a certain value. It is not widely known that almost every part, after proper processing, may be utilized.

\section{Ecodesign}

Designing is a process where the features of the object are gradually defined from general to more and more specific. It involves actions and events that occur between the moment when a problem appears and the time when documentation is drawn that describes the resolution of the problem, which meets the functional, economic, and other pre-defined requirements $[2,3]$. It is a complex process, very important in the life cycle of any product. Decisions made in the design stage affect the costs of product manufacturing and operation $[4,5]$ and determine 
actions that will have to be made in the final phase of the product's life cycle (after it is withdrawn from service). Research has shown [10] that modern recycling technologies give the most significant results if they are implemented at the early stages of product development, i.e. in the design stage.

Ecodesign consists in the identification of environmental issues concerning the product and taking them into account at the early stage of product development [6]. In the literature ecodesign is also referred to as DfE (Design for Environment), environmental design, ecological design, sustainable product design, green design [7]. Moreover, meeting the environmental requirements is considered an advantage in the quality assessment of the product [8].

Ecodesign introduces an additional dimension to traditional design [9]. It involves tasks consisting in a systematic analysis of the effects that mutual interactions of raw materials, manufacturing processes and the final product have on the environment, and in suggesting improvements in the designed technological processes. Ecodesign involves not only the optimization of the production process; it is the optimization of the entire life cycle of the product based on a comprehensive analysis (starting from the delivery of raw materials, production processes, product use and withdrawal). It allows for the identification of "critical" points to plan the strategies of improvement (focusing on the most critical ones, often having to compromise).

As a result of such an approach to design it is possible to deliver products, which are made with technological processes that avoid the use of hazardous substance and toxic waste. That can only be achieved by finding the source of the problem; for a product, it is necessary to focus on the design stage.

When they buy a piece of equipment, people increasingly often ask whether the product was made in line with environmental requirements: if it saves water, electricity, and what will happen to the product when it reaches the end of its life cycle. It is therefore extremely important to take these issues into account early on in the design stage, because all the decisions taken at this stage will have an impact on the properties and functioning of the product and on the costs arising later in its life. The identification of possibly all the important environmental requirements at early stages of product development plays a crucial role further in the life cycle of the product $[5,6]$.

In general, in ecodesign the following aspects are taken into account [11]:

- saving natural resources and using renewable materials in the production process,
- the possibility to reuse materials - taking into account the recycling of raw materials,

- minimizing the of hazardous substance, elimination of materials that cannot be recycled,

- reducing harmful effects on humans and the environment during operation withdrawal from use (elimination of end-of-life products and packaging),

- use of environmentally friendly packaging.

The main elements of the ecodesign process include [11]:

- the identification of new product ideas, resulting from the marketing strategy and environmental policy of the company. The ideas are analyzed, evaluated and selected in terms of environmental innovations. Next, the selected solution is developed into a detailed concept, taking into account environmental demands, technical possibilities and customer feedback,

- assessment of the new product concept in terms of technical and economic conditions, where the environmental impact of the designed product is compared to the properties specified in the project. The developed concepts have less environmental impact. Further work focuses on the few selected products, and the actual conditions for the development of the selected product are considered,

- technical and marketing research, involving the precise description of the development process and identification of objectives to be reached. Product prototype is then created and tested to verify if it meets the parameters defined before. The product is developed technically and marketing-wise, and later it is introduced on the market.

It is a common problem of the design stage that designers lack professional knowledge of ecology. The knowledge about the influence of materials and processes on the environment, and product recyclability options are usually beyond the competence of the designer. Hence the growing importance of specialized IT systems which support designers in the decision making process during environmental design. Due to their cost and limited functionality, however, there is a need for other such systems [12].

\section{Recycling-oriented method to support ecodesign}

Our method, which facilitates product recyclability evaluation at design stage, is based on the recycling product model (RpM) and agent technology. The RpM, developed during the geometric modelling phase, includes the data necessary for a comprehensive product recyclability evaluation already at the 
design stage, allowing the designer e.g. to select appropriate solutions that facilitate future disassembly and to choose materials most suitable in terms of future recycling. The RpM has been implemented to the CAD 3D system and served as a basis to design an IT tool (an application), which facilitates the design process taking into account the recycling aspects. The application includes also a knowledge base, which accumulates the information on already completed projects. It is used by the system to offer suggestions when new products are designed, taking into account the aspects related to recycling. The software of the application uses the agent technology [13]. Agents follow the work of the designer in the 3D CAD system, monitor the changes made in the design, assess their impact on the parameters relevant to recycling, and provide suggestions of product improvements to facilitate recycling. The use of the agent technology and RpM in the application enabled automatic support for the recycling aspect of designing, without having to re-examine the product structure, manually aggregate the parameters relevant for the adopted method of product recyclability evaluation, and to re-introduce them to third party systems. The following is a description of the practical application of the system in recyclability assessment of a sample product modeled using a CAD 3D system.

\section{Analysis of product recycling cost}

Aspects related to product recycling are undoubtedly linked to different costs. First, if recyclability is taken into account at design stage, it will generate costs related to product development and introduction of improvements. Second, recycling in itself is associated with certain costs, although a product should be designed to minimize the cost, and to maximize the benefits from the recovery of raw materials. Pro-recycling actions are not always related with incurring costs: recycling may also generate profit, for example, from the sale of recovered materials which may be reused as raw materials.

At the design stage we cannot precisely calculate future recycling costs or revenues associated with the recovery of materials, but both, profits and costs, can be estimated. These costs are related to the current situation on the recycled materials market, i.e. to the purchase prices of raw materials. Additionally, there are costs incurred by recyclers who disassemble products and recover re-usable material. Recycling technologies, available during product disassembly and recycling, are also important. Other costs are also associated with the transport of end-of-life products (e.g. costs of product withdrawal from the market, fuel costs), storage of such products, and the storage of selected products and materials after disassembly. When estimating the cost of recycling at the design stage we should compare them for different variants of the same product and select the best solution (most cost-efficient) with the highest possible recovery rate. However, it should be emphasized that reducing the cost of recycling may not change the functionality of the product or affect consumer's interest and product safety. Therefore, the method described here is based on estimates and is used to compare the costs of recycling of various versions of the designed product [14].

\section{Disassembly cost}

The cost of disassembly is a component of the total product recycling cost. One of the key factors influencing disassembly cost is its time, which in turn depends on the type of disassembly and uniformity of joints.

In the case of uniform joints, fewer tools are needed to disassemble the product, which saves time and reduces costs. Since disassembly can be manual, automated or mechanical, there are two types of disassembly costs:

- manual disassembly cost - where disassembly time is key, as it affects the pay of the worker - the only cost in this case. When the worker uses electrical or pneumatic tools, the total cost includes also the energy consumed by the tools. The values are so low, however, that most often they are disregarded in the estimates of the total cost,

- the cost of mechanical and automated disassembly - it is a much more complex case, most often considered individually. This means that it is only possible to calculate the costs for a particular disassembly line, the structure of which depends on the dismantled products, the resources of the organization and the available technology. Therefore, apart from the employee's salary we have to consider the cost of machinery and equipment depreciation, as well as the costs of energy and other infrastructure, which is very difficult to estimate if there is no specific disassembly line.

\section{Recycling cost}

Apart from disassembly costs, recycling costs are the second component which affects the total recycling cost. The factors that influence its value include the weight of the material and revenue from sales, in the case of material recycling, or the cost of dis- 
posal or storage, in the case of disposal or storage. According to the law, recycling is understood as material recycling or raw material recycling, with the exception of energy recycling. Therefore, due to the type of joints between parts and materials, certain assumptions can be made:

- permanent joints are not removable due to excessive cost and imprecise separation of material components,

- sets or parts made of recyclable materials generate a revenue from the sale of such sets or parts to recycling organizations. Such sets include:

- sets permanently joined, consisting of at least one part made of a material with limited compatibility in relation to other parts, provided that it does not adversely affect the recovery of raw materials,

- permanently joined sets consisting of compatible parts,

- temporarily joined sets, where regardless of material compatibility single material parts may be separated in disassembly,

- sets or parts made of disposable or storageable materials generate losses resulting from fees charged by recycling companies. Such sets include:

- sets permanently joined, consisting of at least one part made of a material with limited compatibility in relation to other parts, provided that it adversely affects the recovery of raw materials,

- permanently joined sets consisting of at least one part made of material incompatible to other parts,

- parts made with harmful materials.

\section{Method for estimating the total product recycling cost}

The method assumes that each part of the product may be utilized in several ways:

- disassembled and sold as homogenous parts,

- disassembled and sold as a combination of (compatible) parts,

- disassembled and utilized as waste, and

- disassembled and utilized as hazardous waste.

Additionally, the disassembly of every joint, defined as possible to dissasemble, is associated with a specific cost in time, labour, and the use of tools chosen by the designer. All the information is used to create a recycling cost estimate for the given product.
The method takes into account two basic factors which affect the recycling cost: the first is the cost of disassembly, and the other is the cost of disposal and recycling of materials used in the product.

We may generally assume that recycling cost is the difference between the profit gained from selling recyclable and reusable materials, and the total costs incurred for disposal or storage.

$$
\begin{gathered}
\text { RECYCLING COST }=\sum_{i-1}^{n} \text { REVENUES } \\
-\sum_{i-1}^{n} \text { COST. }
\end{gathered}
$$

The total recycling cost is the total revenue on materials which may be sold after disassembly, and the cost is the total cost incurred for disassembly, disposal of hazardous waste, transport to waste disposal landfill.

$$
\begin{gathered}
\mathrm{K}_{\mathrm{RW}}=\sum_{\mathrm{i}=1}^{\mathrm{n}} \mathrm{K}_{\mathrm{MD}} \\
-\left(\sum_{\mathrm{i}=1}^{\mathrm{n}} \mathrm{K}_{\mathrm{UMN}}+\sum_{\mathrm{i}=1}^{\mathrm{n}} \mathrm{K}_{\text {Odpad }}+\sum_{\mathrm{i}=1}^{\mathrm{n}} \mathrm{K}_{\text {Dem }}\right)
\end{gathered}
$$

where $K_{\mathrm{RW}}$ - product recycling cost, $\mathrm{K}_{\mathrm{MD}}$ - cost of good materials (recyclable and reusable), $\mathrm{K}_{\mathrm{UMN}}$ - cost of hazardous waste treatment, $\mathrm{K}_{\text {Odpad }}$ - cost of waste, $\mathrm{K}_{\text {Dem }}$ - disassembly cost, $\mathrm{n}$ - number of materials in a given product

$$
\begin{aligned}
& \sum_{\mathrm{i}=1}^{\mathrm{n}} \mathrm{K}_{\mathrm{MD}}=\text { weight } \times \text { price }[\mathrm{kg} \times \mathrm{zl}], \\
& \left.\sum_{\mathrm{i}=1}^{\mathrm{n}} \mathrm{K}_{\mathrm{UMN}}=\text { weight } \times \text { price_[ } \mathrm{kg} \times \mathrm{zl}\right], \\
& \sum_{\mathrm{i}=1}^{\mathrm{n}} \mathrm{K}_{\text {Odpad }}=\text { weight } \times \text { price_[ }[\mathrm{kg} \times \mathrm{zl}], \\
& \quad \sum_{\mathrm{i}=1}^{\mathrm{n}} \mathrm{K}_{\text {Dem }}=\text { disassembly_time } \\
& \times \text { unit_cost_of_disassembly_[rate } \times \mathrm{h}] .
\end{aligned}
$$

The longer the disassembly of end-of-use products, the greater the recycling cost for recovery organizations. Hence, it is most advantageous to design goods with a view to effective and smooth disassembly.

Final recycling cost will depend on the recycling groups the product will be divided to and on the materials that will be recovered. If during the disassembly we recover combined materials, consisting of steel of different quality (higher and lower quality), further disassembly of which is not possible, 
the recovery cost will depend on the price of lower quality steel. Parts made of plastic and steel, combined in a manner that does not allow for separation, will generate smaller profits, as it will not be possible to recover high quality, pure plastic. Parts made of nonferrous metals, steel, and plastic, but inseparably combined with hazardous materials, should be considered as hazardous waste. Neutralization of such a material mix will require incurring additional costs.

In the approach involving ecodesign, components made of many parts and materials which cannot be separated are known as material mixtures, and they are treated as compounds.

\section{Case study}

Recycling-oriented product assessment provides information on the estimated product recycling cost. To carry out such an analysis the authors prepared sample product models in CAD 3D. The models, later subjected to the recycling-oriented product assessment, involved large- and small-size household appliances. They included various combinations of joints and allowed the authors to assign extended material and disassembly attributes necessary to estimate product recycling cost. Figures 1-4 shows the analyzed modelled products in the CAD system.

Large size models, such as the washing machine or refrigerator, contain a large number of parts (200700). Small size models, such as a hair dryer or kettle contain a small number of parts (20-40).

The CAD 3D model with the possible combinations of materials was examined according to the following procedure:

- development of a 3D model of all product components,

- development of a recycling model (RpM),

- recycling-oriented product assessment (calculations of recyclability evaluation measures by the agent system).

In the first step, we made geometric 3D models of the examined product part (or combination). Then, the necessary geometric constraints were defined to determine the relevant geometric relations between the parts. Based on the geometric model (assembly model), the recycling model was developed. Within the recycling model [15] the following were defined:

- product category (type),

- extended material attributes,

- the model of connections between the product elements.

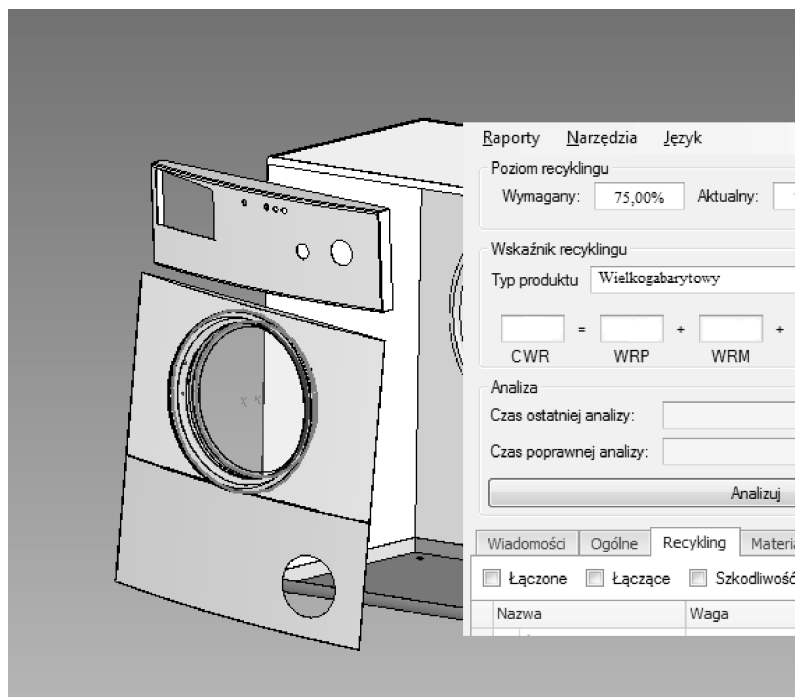

Fig. 1. Washing machine model in CAD 3D system with the agent system interface.

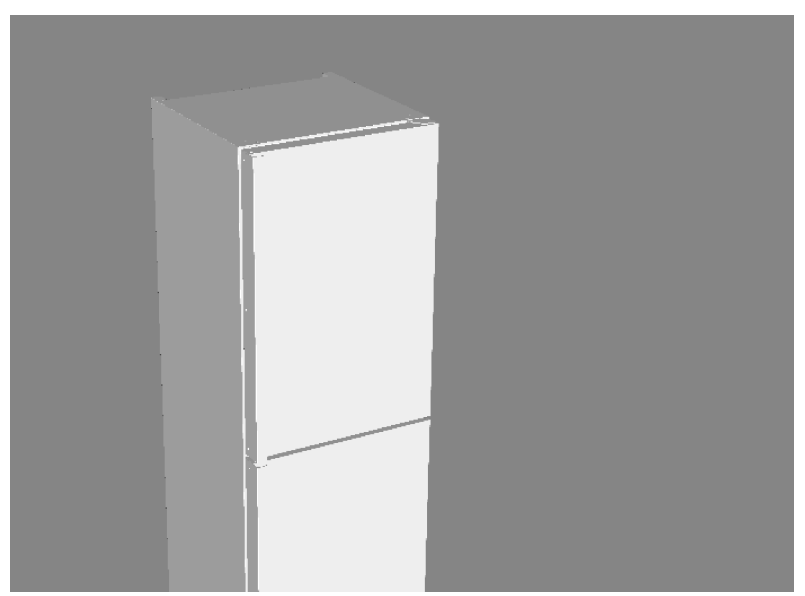

Fig. 2. Refrigerator model in CAD 3D system.

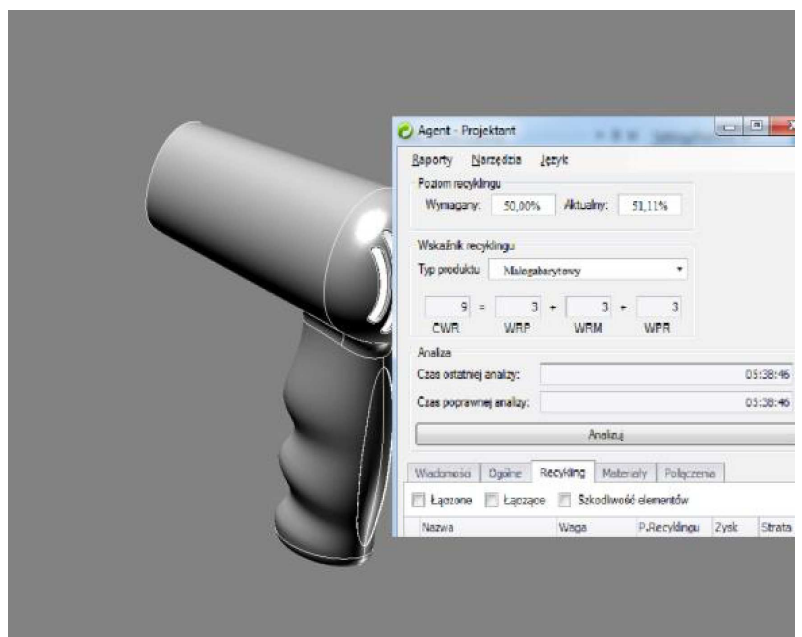

Fig. 3. Hair dryer model in CAD 3D system with the agent system interface. 


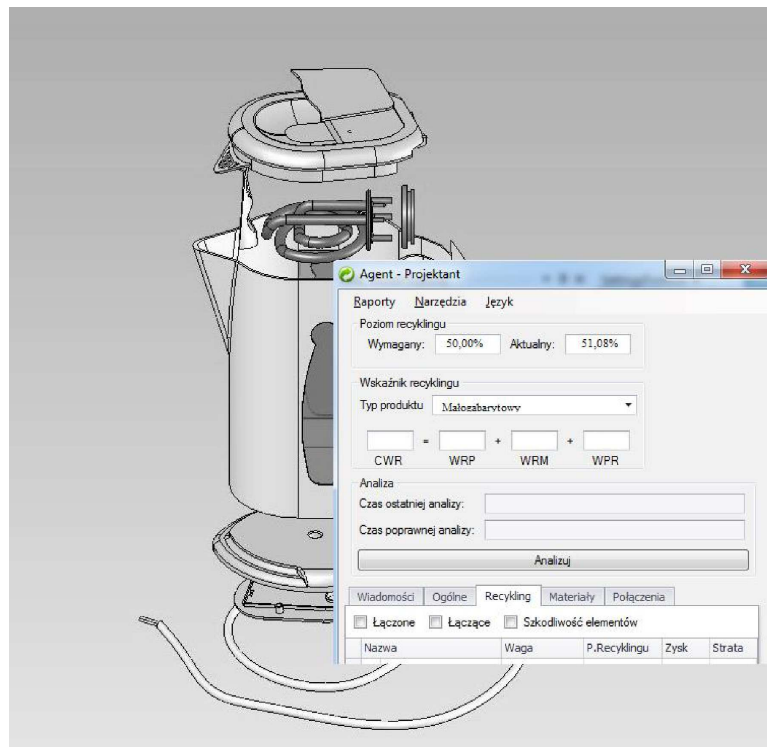

Fig. 4. Cordless kettle model in CAD 3D system with the agent system interface.

The recycling model is made in a $3 \mathrm{D}$ CAD environment through a graphical user interface built in the CATIA system. The assignment of the product to a specific type is made in the project's global settings window. In the field "product type" we indicated the type (category) of the model uploaded to the CATIA system. The available options include "small household appliance", "large household appliance", and "other". The database with extended material attributes, defined earlier, was also uploaded. It included the basic groups of construction materials and plastics.

In the analysis we assumed that the average labour cost of a worker disassembling the product was PLN 10/hour, and the purchase price of materials was as at the day of analysis. The recycling cost was affected also by time and the so-called depth of disassembly. The analysis did not take into account the costs of product acquisition on the market and the cost of waste management.

As a result of the analysis, estimating the product recycling cost, the authors obtained the following data (see Table 1).

Table 1

Comparison of estimated recycling cost of household appliances from a CAT system.

\begin{tabular}{l|c|c|c}
\hline Product & $\begin{array}{c}\text { Weight } \\
{[\mathrm{kg}]}\end{array}$ & $\begin{array}{c}\text { Disassembly } \\
\text { time } \\
{[\mathrm{min}]}\end{array}$ & $\begin{array}{c}\text { Estimated } \\
\text { profit } \\
{[\mathrm{PLN}]}\end{array}$ \\
\hline $\begin{array}{l}\text { Automatic washing } \\
\text { machine }\end{array}$ & 60 & 60 & 31.02 \\
\hline Refrigerator & 50 & 50 & 8.46 \\
\hline Hair dryer & 0.9 & 12 & 0.98 \\
\hline Cordless kettle & 1.5 & 15 & 1.23 \\
\hline
\end{tabular}

The estimated profit was defined as the revenue from product recycling minus the costs incurred. The costs may include the utilization of hazardous materials, storage, wastewater.

As shown in Table 1, the greatest profit was estimated to come from the recycling of a washing machine and refrigerator. These are large size appliances with a weight of $50-60 \mathrm{~kg}$, with steel as the main material. Small size appliances, weighing 0.9-1.5 kg, with plastic as the main component, may generate smaller profit. However, it is important to note that recycling of small-size household appliances may be profitable as well.

\section{Summary}

The study made it possible to evaluate the designed product before its production. As a result, it is possible to compare several variants of the product and choose the one with better disassembly time, recyclability and recycling cost.

This original system supporting ecodesign is based on a method that estimates recycling cost. Two basic factors have been considered: the first is the cost of disassembly, and the other is the cost of disposal and recycling of materials used in the product. The use of the agent technology to support the design of environmentally friendly products led to the automation of the decision-making process in design, and the application of the system in design offices with distributed structure.

\section{$\underline{\text { References }}$}

[1] Guranowska-Merkisz A., Reverse logistics as a key element of Polish logistic system [in Polish: Logistyka recyklingu odpadów, jako jeden z elementów systemu logistycznego Polski], Warsaw, Prace Naukowe Politechniki Warszawskiej, pp. 89-96, 2010.

[2] Sielicki A., Jeleniewski T., Elements of technical design methodology [in Polish: Elementy metodologii projektowania technicznego], Warsaw, WNT, 1980.

[3] Krick E.V., An introduction to engineering and engineering design, New York, Wiley, 1965.

[4] Dostatni E., Managing the design process using decentralized AI methods [in Polish: Zarzadzanie procesem projektowania z wykorzystaniem metod rozproszonej sztucznej inteligencji], $\mathrm{PhD}$ thesis, Poznań, Poznań University of Technology, Faculty of Mechanical Engineering and Management, 2004.

[5] Weiss Z., Dostatni E., Decisions involving recycling made in the product design stage [in Polish: Decyzje podejmowane $w$ procesie projektowania wyrobu uwzględniajace recykling], in: Innowac- 
je w zarządzaniu i inżynierii produkcji, R. Knosala [Ed.], Opole, Oficyna Wydawnicza Polskiego Towarzystwa Zarządzania Produkcją, 2011.

[6] ISO/TR 14062, Environmental management - integrating environmental aspects into product design and development, 2001.

[7] Kurczewski P., Lewandowska A., The role of Life Cycle Management in the creation of technical objects and technologies [in Polish: Zasady pro środowiskowego projektowania obiektów technicznych dla potrzeb zarzadzania ich cyklem życia], Poznań, KMB Druk, 2008.

[8] Hamrol A., Mantura W., Quality management [in Polish: Zarzadzanie jakościa, Warszawa, PWN, 2006.

[9] Burchard-Korol D., Ecodesign - holistic approach for the design [in Polish: Ekoprojektowanie holistyczne podejście do projektowania], Problemy Ekologii, vol. 14, no. 3, Mysłowice, The Cardinal August Hlond University of Education, 2010.

[10] Weiss Z. et al., Concurrent engineering of construction and technology of rotating machine elements [in Polish: Wspótbieżne projektowanie konstrukcyjne $i$ technologiczne obrotowych elementów maszyn], Report from the Project KBN no. 7 T07D003 08, Poz- nań, Poznań University of Technology, Institute of Mechanical Technology, 1998.

[11] Adamczyk W., The ecology of products. Quality. Life cycle. Design [in Polish: Ekologia wyrobów. Jakość. Cykl życia. Projektowanie], Wasaw, Polskie Wydawnictwo Ekonomiczne, 2004.

[12] Dostatni E., Karwasz A., IT systems supporting ecodesign [in Polish: Systemy informatyczne wspomagajace proekologiczne projektowanie], Zarządzanie Przedsiębiorstwem, 2, 13-22, 2009.

[13] Wooldridge M.J., An Introduction to MultiAgent System, Wiley, 2002.

[14] Dostatni E., Karwasz A., Diakun J., Method for estimating recycling costs of household appliances at product design stage [in Polish: Metoda szacowania kosztów recyklingu wyrobów AGD na etapie projektowania], pp. 298-306, 2013.

[15] Dostatni E., Diakun J., Karwasz A., Grajewski D., Wichniarek R., Ecodesign of products in CAD $3 D$ environment with the use of agent technology [in Polish: Proekologiczne projektowanie wyrobów w środowisku CAD 3D z zastosowaniem technologii agendowej], Poznań, Wydawnictwo Politechniki Poznańskiej, 2014. 